\title{
A voice from the margins: Investigating the African Adventist rationale on the quest for female ordination
}

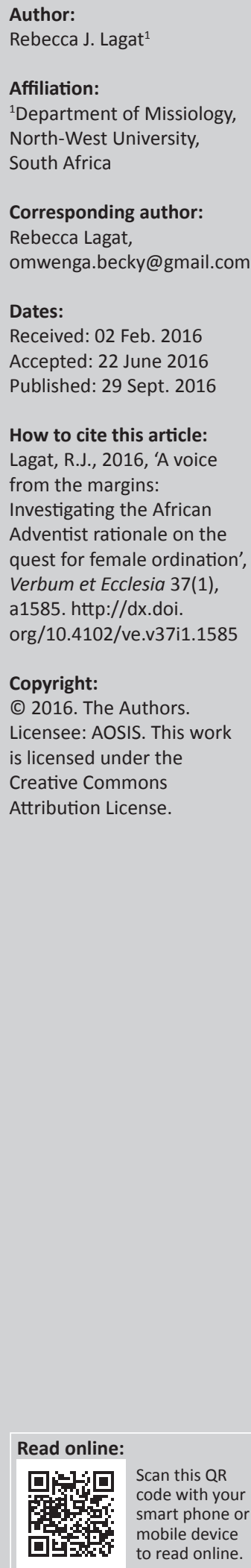

\begin{abstract}
Discussions surrounding women's ordination reached a peak with the 60th General Conference Session (GCS 2015) of the Seventh-day Adventist (SDA) Church. A report compiled by a section of delegates from the East-Central Africa Division - Biblical Research Committee indicated that this continent was not yet ready to ordain women as pastors. In light of the report, this article aims to investigate the rationale of such a stark decision. Firstly, the report shows that African Adventist women theologians were omitted from the discussions - a lack of good will from the church leadership towards the females as the majority of the membership. Secondly, the decision against ordination of women is suspect and biblically inconclusive. Through an overview of literature on a biblical missional design, the article postulates: Contextualisation and theologising are necessary for Africa, but the SDA Church must remember that globally both theology and culture are subject to the biblical guidelines, and thus to God's missio Dei as well.

Intradisciplinary and/or interdisciplinary implications: This article balances cultural contextualism and gender relations - challenging a cultural bias through a missional hermeneutic. This can lead to fairer representation of African women in Adventist church structures and reroute the equality discourse in light of the missio Dei. The study intersects with cultural theory, social analysis and biblical hermeneutics.
\end{abstract}

\section{Introduction}

\section{Background to the report}

In the past months, the highest authority within the Seventh-day Adventist (SDA) Church, the General Conference (GC), planned a meeting to deliberate on a crucial and yet contentious issue in its church history, namely ordination of women. Represented in this historic event were delegates from denominations worldwide, including Africa. Prior discussions on the issue locally and internationally have already confirmed predetermined positions from delegates opposed to women's ordination, and those proposing the transition.

A report compiled by a section of delegates from the East-Central Africa Division - Biblical Research Committee (ECD-BRC) (ECD-BRC 2013) indicated that Africa was allegedly not yet ready to ordain women as pastors. Therefore, the author of this article investigates the rationale of such a far-reaching decision. The article highlights two important concerns. Firstly, the report compiled indicates participation of African Adventist theologians and scholars, and secondly, it is obvious that African Adventist female theologians were left out of the discussions. To confirm this important issue, the article takes note of the membership of the ECD-BRC group's choice, which highlights its constitution and the language used to express a certain gender in the discussions.

\section{Critical analysis of the report}

This article analysed the content of the report and intended structural analysis that brings forth particularly sections suggesting gender bias.

\section{Evidence of gender bias}

The approach and style of the report reveal evidence of gender bias. Firstly, although the presenters were categorised according to their academic and professional specialisation, there are no indications that Adventist female theologians were consulted. This was collaborated by the members of the ECD-BRC present at a conference organised by the Adventist University of Africa (AUA), August-September 2015, where the author presented this paper. When responding to the question, why not include Adventist female theologians in the ECD-BRC discussions, the then 
chairman of the ECD-BRC hinted that they did not see the need to include female theologians because they were not sure of their competence. This clear prejudice and presumption towards female theologians is not only biased but lacks in credibility and evidence.

Secondly, an analysis of word-use also indicated a bias towards one gender. In this case, it is the use of the pronoun [he] throughout the report. Throughout the report, the reader encounters statements such as:

he argued for progressive understanding (ECD-BRC 2013: 69), he has observed the silence of the New Testament (Ibid. 108), according to [him] women may do everything in church, but headship is prerogative of men (ibid. 134), he also argues that priests were males, according to [him] there is, therefore a need to continue to study until ...' (ibid. 121), and so forth. (n.p.)

Seldom can statements be found that indeed denote a female voice in the report which brought together Adventist African scholars and theologians from across the world. The 11-bench membership which consisted of Old and New Testament scholars was made of one gender, the male gender right from the beginning to the end. By the time of the compilation of the report (ECD-BRC 2013:21-22), nothing indicates that any female theologian or scholar had been included, or at the least, consulted for comment. This demonstrates a lack of good will among the church leadership towards its females who form the majority of the membership. The implication here is that female Christians, although in the majority, are disproportionately represented on management levels in many African congregations, including the SDA. According to a study performed on Asian and African women in Christian missions, at least two-thirds of the new Christians in the global churches are females (Gaitskell \& Urban-Mead 2008:489) and yet the management leadership by women remains a hotly and highly contested issue in these regions.

Thirdly, the biblical basis, especially the Pauline passages in 1 Corinthians 11:3-16, 14:34-35, Ephesians 5:23-24, 1 Timothy 2:11-15 and 1 Peter 3:1-3, that the ECD-BRC group used to arrive at its decisions is suspect and inconclusive in itself. This is because of (1) certain expert scholars' views that the Bible is silent on the matter and (2) the fact that the committee rejected the opposite view of the need to ordain women as presented by one of the Old Testament Scholars (ECD-BRC 2013:134-147) claiming that such a view was informed by a feminist movement.

When confirming the decision to oppose women's ordination, the report noted that:

After examination of pertinent Bible passages, most of the Bible students do not find any basis for ordaining women (ECD-BRC 2013:147). So far the obvious answer to the question of whether ordination of women to pastoral ministry is Biblical is 'no' or 'wait till we get more light'. (ECD-BRC 2013:146-149)

The question remains on what authority the committee contends that the Bible opposes women's ordination and, therefore, maintains in a global forum that the biblical answer to the question is a 'no'. This is even more the case, given the fact that the same report also proposes 'a wait till more light is found' (ECD-BRC 2013:149).

Fourthly, the report indicated that 'all' the scholars of ECDBRC except one Old Testament professor did not believe in the ordination of women (ECD-BRC 2013:136), leading to their overwhelming support of the same. One may query whether this response does not entail an act of tyranny of numbers. As the report states:

It has now emerged that the opponents of ordination of women as pastors are many and opposition to the move to ordain women is quite strong. On the other hand, the proponents for the ordination of women are also significant in number and their position is quite strong too. (ECD-BRC 2013:150-152)

Assuming that the GC session was to adopt their second opinion (wait till more light is found), the obvious question remains: Will the committee direct the session to another source other than the one they have wrongly misrepresented by adding to its understanding?

In this regard, the question must be posed: Can the committee's decision to oppose women's ordination be justified by citing the Bible as its basis, seeing that the biblical testimony is in favour of male's ordination? Would it not be better to find another basis rather than misleading many African Adventists who are not cognizant of the hermeneutics behind the doctrine of the sola Scriptura? The article aims to answer these and other relevant questions on gender approached from a biblical hermeneutic.

\section{The misuse of Ellen G. White's writings}

It is noticeable that the report bases some of its findings on the writings of a woman, namely Ellen G. White (EGW). Citing her writings, the report made allusions to ordination as an act of both God and man (White 1880:94, 162) but failed to have an objective view on her opinion on the issue of ordaining women. In the report, the committee presumed and concluded that EGW was not in favour of female ordination. The reason is that, as a prominent female member within Adventist history, she was not ordained even though she held a high position in the Church. Such a characterisation may carry merit, but no unique view is expressed towards understanding the problem at hand apart from the usual tradition of quoting the writings of a female authority as alibi to endorse a preconceived viewpoint within the Church. This practice identifies the common and general weakness among SDA practitioners to quote or misquote the writings of authoritative figures such as EGW whenever they apply their view in public practice.

However, if the participants of the ECD-BRC literally followed the advice of White, the recommendations of other methodologies would have been part of their exegesis. The methodologies in question are concerned with the praxis of how a text should be understood properly. The aim in this case is to liberate people from the oppression they experience 
(Russel 2004:25-27). An appropriate list of these methodologies would include: Biblical theology of mission hermeneutics, post-colonial hermeneutics and feminist hermeneutics. This article opts for the alternative methodology of a biblical theology of mission, based on the missio Dei perspective.

\section{The case for a biblical missional theology}

The result of the report would have been enriching, interrogative and energising. The focus then falls on traditions and cultural perspectives on how the Scripture is interpreted and understood. This includes the belief that the Bible is to be read as a redemptive-historical unfolding of God's purpose, rather than a compendium of theological assertions (Williams 2010:72). Nevertheless, God must remain the central character in the story rather than simply a transcendent power. The words of the Scripture as well should be understood from the context of the experiences of those involved in the narrative.

To address the ambiguities on the whole issue of female ordination and the ECD-BRC report, the article focuses on the position of African women in light of the biblical theology of mission. In this sense the current situation is related to cultural biases against Adventist females in Africa. The aim is not to propose, nor oppose female ordination. It can be argued that, because African society is patriarchal in nature, the best argument against female ordination would be cultural and not biblical as advanced by the ECD-BRC report.

The corrective assumption thus is put forward: although contextualisation and theologising are both necessary for Africa, the SDA Church in the world should keep in mind that both theology and culture are subject to biblical guidelines, and hence subject to God's missio Dei. Therefore, it is a tenable assumption that any decision on female ordination should be a matter for the Godhead, and particularly guided by the Spirit and not by emotions and formations. An idea, construct or decision that supersedes God's guidance, is not only dangerous to the entire body of Christ but ungodly as well. This applies to the social construct of female ordination within an African cultural setting, which will be investigated subsequently.

\section{The issue of female ordination}

The problem surrounding the issue of female ordination is not unique to the SDA Church as a denomination.

\section{Transformation in mainline denominations}

Over the years, many mainline denominations have had to contend with this issue and were forced to make decisions. Although some sectors made progressive decisions, others such as the SDA Church, are still grappling with its internal problems. According to Elizabeth Tenety (2015:31), twothirds of American Catholics (68\%) believe that the church should ordain women as priests. This position is supported by Pope Francis who has questioned the traditional Catholic belief that men are the 'true' church leaders. Nonetheless, such support and views do not exhaust the discussions on the desirability to ordain women within the Catholic spheres; it rather initiated a new discourse on this matter.

Other sections have found comfort in the reality of their cultures and churches that provide a clear platform of expression and practice to interpret and understand the Scripture (Williams 2015:4a). However, others, especially in Africa, are yet to appreciate the objectivity of scriptural exegesis (Phiri 2011:18). This arises from the reality that a few women studied theology within African seminaries - a problem which has led to a small number of them being employed as female professors in the seminaries and as a result, they were not ordained in their churches.

\section{Space for the female voice}

Emphasising the importance of each member within the creation of God, both Pope Paul II and Pope Francis reiterate the need to provide space for women's religious voice and to heed their deep-set experience, wisdom and insight. These two popes concur that such a contribution can transform the attitudes of men towards God's creation and towards fellow human beings. This can be accomplished in a way that purely scientific, economic or political - including cultural approaches would be less likely to achieve (Mckelwee 2015:8).

Cultural guidance, doctrinal beliefs and biased theological persuasions are some of the factors that impede a clear understanding of God's word (Davis 2014), and every Christian, Church institution and profession should be cognizant of this matter. God is the One who ordained men and women together by commanding them (Gn 1:26-28) to multiply and rule over the earth. This must be understood as God's ultimate will for humanity in every generation. His divine intention and will towards all of his creation is a call to worship. Worship, therefore, becomes humanity's primary responsibility to God. In this sense, worshipping is part of God's mission, the missio Dei.

\section{African women and cultural bias}

With regard to culture, women in Africa are institutionally excluded from participating in leadership. The reason is that both the biblical narratives and African society allow women scant space within culture. Christian practice, Jewish monotheism and Islam do not give sufficient recognition to women. The question remains: What is the biblical message about women and culture?

\section{Culture and women's 'small world'}

In order to answer the question above, this article understands culture as integrating systems of beliefs, feelings and values together with its associated symbols, patterns of behaviour and products shared by a group of people - in this case Africans, and particularly, African women (Hiebert 1976:384). In other words, culture is viewed as the phenomenon that 
defines the African women in their daily lives. This includes their knowledge of the Bible, their role in the church, their position in the household and their contribution within a society that is patriarchal in nature. Furthermore, their beliefs and assumptions are guided by phenomena, which comprise their reality, and the perceptions of the nature of their 'small world', as well as their acceptance and their knowledge of how things work for them in this 'small world'.

An African woman's world can be considered 'small', seeing that this context is defined by what others, and especially males and culture, permit them or not. According to Jardim (2014:1), women's exclusion from the public sphere of the monotheistic traditions of Judaism, Christianity and Islam is often expressed by referring to the presence or absence of their voices. In most African societies, this is such a minimal space, hence this context is termed 'small world'.

Women within the SDA churches in Africa, in reality, may not identify with the interpretation above. This is because, unlike many other denominations, the SDA women across the world are integrated into a ministry under the name of Women Ministries Department. This department, which resorts under the Personal Ministries Department, allows women space to participate in the various other activities within the Church, including those of 'leadership'. This is permissible as long as such leadership does not impact on the office of the pastor, which is understood and regarded as the highest office within the local church.

Ironically, Adventist women are allowed to preach, teach and even conduct Bible studies. However, regarding pastoring a congregation, they are disqualified by virtue of gender. This understanding and practice is often justified by quoting and borrowing from Paul's advice to Timothy (1 Tm 3:2), and especially the statement that reads '... the husband of one wife ...'

\section{The Seventh-day Adventist tradition and the male prerogative}

The SDA tradition regards males as having the prerogative to be ordained because the SDA missionaries accentuated Paul's advice that refers to 'the husband of one wife'. In the process the SDA transferred this rendition to the Africans more than a century ago, and it has been preserved up to date. While arguing on the legitimacy of marrying one wife, the SDA Church teaches that men are to be considered high priests within their homes, and thus the same position is adopted in church leadership. For an extended period, such teachings were applied to male elders but because the SDA Church has appointed female church elders, the interpretation of this specific passage has since brought confusion in many African churches where women are currently allowed to hold the post of an elder.

\section{Indigenous experiences and cross-cultural clashes}

The women from an African theological viewpoint defined their world and experiences in terms of beliefs, practices and values which made them understand their 'small world' as females in Africa. These women were relating their cultural experiences to the teachings of their faith and religions. They discussed matters of leadership, mission, education, ordination and Scripture. It is apparent from the literature that African males showed little or no interest in issues of women to date. The male bias towards females based on culture, family and sexuality apparently has continued to disadvantage women in certain positions in the church, at home and even in society at large. Such forms of segregation are based mainly on their female marital status, sexuality and cultural persuasions (Gaitskell \& Urban-Mead 2008:495).

Within the SDA's African domain, programmes define members in terms of their age, gender, as well as membership status. The SDA's personal ministry department defines the roles of women; for example, Shepherdesses, women ministries, Dorcas society, single women and widows. Even though these departments exist for the good of the church, they often compete for power and recognition, which raises questions about the existence of such groupings (Tim 2014:4).

These programmes are not indigenous to Africa but imported from the West. This leads to a clash of cultures on what is ideal for women programmes in Africa and what is practical. For example, the Western definition of meeting times does not seem to resonate with the African women's context, given the position and roles society dictates to them. As a result, women ministry programmes are monopolised by educated Adventist women within the cities. This is where African women's leadership and membership roles are defined, which gives the false impression that African villages and societies are evangelised. However, although these women attend Adventist churches in large numbers, their ChristianAdventist practices are filled with folk religion and Christianity. This is the context where African Adventist women and the Gospel meet.

\section{Challenges faced by Seventh-day Adventist women in Africa}

Although African Adventism expands at the one end (Bauer 2009:3), on the other end of the scale the church is growing with members who are seen to be corrupt, dishonest, tribal, jealous, formal and emotional, to name a few issues (Wari 2009:19). Those affected mostly are the women and youth. Firstly, the youth suffer because the African Adventism of yesteryears is faced with the reality of changes brought about by technology and postmodernism. The 'how' and 'why' of meeting the needs of its youth are a thorn in the flesh of SDA churches in Africa at present. Secondly, the women are sandwiched between, on the one hand, following the doctrines of the church which are not as easily understood as before, seeing that the African Adventist pastor is busy with the 'kingdom's business', and on the other hand, women face daily decisions which impact on their ambivalent role as modern women as well as faithful Adventist believers. 
The author is informed that many African Adventist pastors have not been overseeing their congregation because of pursuing other interests, such as the desire to upgrade their education, at the cost of the calling they received. Moreover, in this category there is an intense power struggle and an effort to raise the Church's standards of leadership to match those globally. The congregations in Africa, therefore, are led by untrained church elders and others, and dedicated women have taken the lead. The work of the pastors has been reduced to merely attending church boards and receiving reports. In some areas, pastors no longer preach the Gospel. The author refers to these activities as 'Kingdom's business'.

These are some of the common challenges faced by an Adventist woman in Africa at present. Nonetheless, the real challenges that need to be tackled are the ones faced by the SDA Church worldwide and the African continent in particular. The Adventist Church in Africa must appreciate the extent to which education and technology have developed and are impacting on Africans at large and Adventists as well. Whether African Adventism and male-dominated theologians agree or not, the cultural wave of change is a present reality that needs to be factored in. African women are increasingly becoming more educated and modernised day by day. Unfortunately, Christianity and Adventism are progressively losing their attraction. People are clamouring for new ideas, as well as a better understanding and interpretation of Scripture. Intelligent choices and the striving for wisdom do challenge the field of scholarship, and there is increasing research on these topics.

The Adventist women of yesteryear have undergone deep-set changes. More opportunities are becoming available for women believers both locally and abroad. The African SDA women can no longer be restricted and restrained by the same culture that is oppressing them. The SDA Church should be prepared, willing and proactive in nature regarding the full spectrum of life. A paradigm shift is necessary in the manner which church, seminaries and missionary enterprises are dealt with. The question, however, remains: Is ordination an appropriate solution to the problem? It is clear that the last word is not yet spoken on this issue. One fact is, however, clear: the church authorities should refrain from side-lining Adventist female theologians in church activities in the future.

\section{The corrective: Biblical Theology of mission}

The place of women in the biblical theology of mission reaches back to creation, as mentioned previously. However, it must be understood from the outset that most readers of the Bible would rather exclude women from the discussion because of what is generally misunderstood as the biblical endorsement of patriarchy. In Africa, this 'biblical' notion was to be challenged because of the transformation of society after colonialism.

The arrival of Christianity was accompanied by colonialism, but also brought education to Africa. As a result, many
African women became learned. A number of them even went as far as joining the men within institutions of higher learning to study theology and mission. Gradually, and aided by their fellow women in other parts of the world, African women theologians became interrogative. This saw them joining other women worldwide in advancing feminist theologies. This enabled them to question their position in the church and in mission. The first women theologians in Africa consisted of religious learned women from different faiths such as Judaism, Islam, Hinduism, African traditionalism and Christianity. According to Nadar (2012:270), these women shared a common focus; they began to theologise from within their contexts. They had a simple approach to theology, by sharing stories and listening to one another from their contexts.

\section{Critique of Seventh-day Adventist's views on women}

However, as was shown previously, there is yet another attempt to advance the campaign against women as God's ordained missionaries. These proponents cite prominent patriarchs and prophets in the Old Testament, as well as the appointment of the twelve apostles in the New Testament (all of whom were males), as proof that God did not call women into this ministry. These are some of the views held by Seventh-day Adventists on various forums on the internet. Examples can be found on the following web pages:

- http://www.ordinationtruth.com/

- http://www.ordinationtruth.com/category/adventisttoday/

- http://www.ordinationtruth.com/category/adventistworld/.

In light of the arguments stated above, the following points should be made. Firstly, although this article does not question the Old Testament system of patriarchs and prophets, it holds the view that Judaism, which was as heavily patriarchal as any other system in human history, was flawed and cannot be considered as an appropriate example of a way of life. Only a life in Christ provides hope to human beings who belong to one cultural system or another. Secondly, it should be noted: Ironically, while many may agree with these arguments, there remains one undisputed fact, even by the SDA scholars (Paulien 2011:85), namely, that God's mission and biblical testimony presents God as unpredictable, for God's ways and thoughts are not humans' ways or thoughts (Is 55:8-9).

\section{Critique in light of a missional hermeneutic}

For purposes of space, this article will consider the overall definition of a missionary as a person who engages in God's missio Dei as a participant and not an owner of that mission (Kemper 2014:188). In other words, mission belongs to God - the Creator (Gn 1:1) and Re-creator of the universe ( $R v$ 21:1). The term 'belonging' is further understood to mean that God is the sole Owner of mission. This sole ownership, therefore, 
defines God (Triune God - the Father, Son and the Holy Spirit) as the Initiator, Sustainer and Fulfiller of mission and also as the first missionary, who seeks, saves and restores humankind and the world (Ewell 2012:386).

According to modern research, missio Dei at Willingen gave a strong Barthian rendition of mission as the work of the Triune God - indeed, a veritable missionary God. The mission of God is viewed as the foundation for the church's mission, and 'the mission of the church ensues from the nature of the church as the Body of Christ', according to the 1982 WCC Statement on mission and evangelism, reflecting the spirit of Willingen.

The situation is that individual believers understand Scripture from their own perspective, and the SDA Church, especially the Africa's rendition of mission, follows the traditional way expounded by the Seventh-day heritage and theology of mission. The SDA theology of mission is derived from the following words; 'mission' and its derivatives used in this study include both the traditional meaning of missions converting men of other faiths to Christianity and the meaning of evangelism calling back those who have apostatised or are gradually backsliding, thus signifying any activity with regard to human's salvation. Depending on the historical context, the scope of 'mission' refers to either the population of the USA, or that of the whole inhabited world (1977 PGD, FSDA xv.1, taken from the foundations of the SDA message and mission by Gerald Damstgeet [1977]).

In light of this fact, the article adopts Bosch's argument that an authentic hermeneutic is always missional (Bekele 2011:153). This interpretation is important because it makes room for what the Adventist systematic theology would term progressive revelation. This is understood as God's continuous unfolding of the prior revealed truth. Without the unfolding of such inspired truth that builds on previously revealed truths and not negating it, the SDA Church would not exist (Damstgeet 1991:77-92). Even more, this interpretation includes what current scholars in missiology view as an approach leading to humility, continued conversion, repentance, mutual correction, on-going learning and a strengthening of Christian unity (Bekele 2011:154).

From the aforementioned, it is plausible to argue that the body of Christ represented by the membership of the church on earth ought to be ready and willing to partake in God's revelations and especially in his progressive revelation throughout the ages. This aligns with the command of Christ in the New Testament as presented in Matthew 28:18-20. According to this commission, the apostles are called upon to enter the whole world and make disciples of all nations. The call is not directed to males alone. This entails a resounding call to make disciples but is preceded by the command to preach the Good News of salvation. The question can be posed: If the work of discipling all nations does not exclude women, why should the work of leadership exclude them?
It must be kept in mind that the phrase 'all work' refers to God's mission of salvation. Worship defines the ultimate goal of missions, which is God's glory and not humans' enterprise, as explained by Piper (2010:15). All responsibilities defined by the SDA church that separate men and women in ordination, touch on important issues such as officiating in marriage, baptism and leading in Holy Communion - to mention but a few. According to this position, such a work is sacred and cannot be handled by a woman. (On this matter see: 'answers to questions about female ordination, some fundamental questions' available at http://www. adventistsaffirm.org/article/25/women-s-ordinationfaqs/1-answers-to-questions-about-women-s-ordination).

In contrast to the views above, this article argues that denying ordination on such grounds is practicing selective theology. This is because the SDA Church teaches the sanctity of the body of Christ, that is, the church as representative on earth, but above all with Christ Jesus as the Head. Thus, it can be argued that, if there is only one body and one Spirit (Eph 4:4-6) and also one Lord of all (Mt 23:8), then issues of leadership and ordination should not form the basis of the modern church.

\section{Corrective of a biblical theology of missions}

Corrective of a biblical theology of missions can be understood from Wright's (2010:301) argument that the whole world entails God's mission. This implies that all creation, including human beings, owe their existence to one purpose, that is, to participate in God's mission. Such is the analysis that can be drawn directly from reading into the biblical texts and drawing lessons or testimonies of God's people and their involvement in God's mission from the beginning to the end.

It is evident from the biblical testimony that all humans are united in creation (Gn 1:26-27) and recreation (Gl 3:28) in worship to God and not missions, which also applies to leadership in the church. This article considers missions as defined by culture, religion and theology. Unlike mission, missions hold different connotations for different people. A striking example is that of missions abroad as compared to local missions. The missions abroad will be defined by the problems and issues abroad, whereas local missions will be determined by circumstances at home. Therefore, the question needs to be posed why the church capitalises on issues of women's ordination. Some arguments point out that women were not given the role of the priesthood in the Old Testament. However, this view contradicts Scripture that teaches that there is one high priest in heaven, namely the Lord Jesus (Heb $4: 14$, cf. 6:20 and 7:3). From this follows that all the believers belong to the family of royal priesthood (1 Pt 2:9).

A biblical theology of mission does not segregate people along the lines of gender, status, religion, culture, race or nationality. This insight is derived from Wright's (2006:29-46) definition of a missional hermeneutic. His interpretation starts off with the assumption that the whole Bible conveys the story of 
God's mission through God's people in their engagement with God's world for the sake of the whole of God's creation. This holds implications for anyone willing to be made God's instrument in the missio Dei. To participate in God's mission is to take part in his core business, which requires only one qualification, namely obedience (Piotrowski 2011:378).

Such a biblical theology identifies some of God's faithful and obedient servants (Gn 12:1-3). Many of them were people of faith. They trusted God in their engagements with him. In return, God blessed them and made them prosper. Those who disobeyed God were punished, irrespective of gender. Similarly, according to the biblical narratives, God used several women to fulfil his will (Jude 4:4-5; Es 8:15-10; John 4:39-42). The same applies to women presently. The message is conveyed that God is waiting to use them in his mission if they are ready and willing to obey him. This biblical message holds true for every woman. God also has a special place ordained for females in his mission.

Theologians, preachers, men and women alike, often use writings as a way to endorse particular practices, speeches or decisions without sufficient reflection on how these statements are in accordance with the context and time. This laizzes faire attitude shown by those who are commissioned to do biblical exegesis is neither acceptable nor desirable in terms of modern-day scholarship.

If the SDA Church did not cite White's writings selectively, they would also take heed of her warning to the church against becoming consumers of other people's thoughts. White (1903) states:

It is the work of true education to develop this power, to train young people to be thinkers, and not mere reflectors of other people's thought. Let students be directed to the sources of truth, to the vast fields opened for research in nature and revelation. (p. 17)

\section{Conclusion}

The issue of women's ordination will remain a proverbial thorn in the flesh of the SDA Church, for as long as the male leaders in the church do not move away from the belief that they have the prerogative to the message and mission of God. Following on the discussion in this article, it is evident that African Adventist male theologians who deliberated on the issue of women's ordination in Africa were not only biased in their discussions, but also in their decision making. Their understanding of Scripture was not only traditional but also limited to the cultural perception of the minority male theological scholars.

At stake, therefore, is the Church's understanding of the work of God's mission, which is not dependent on male actors but on God himself. As the Owner of his mission, God does not favour gender, race, status or affiliation. God's mission, which includes the various aspects of the missio Dei does depend on human instruments. One of these instruments is his established church, of which the body comprises all the believers with Christ as its Head. In God's church, there are 'women and men alike, masters and slaves, Gentiles and Greeks; young and old' (Galatians 3:28; cf. 1 Corinthians $12: 13)$, all have the calling to work for God and only obedience to his ways defines them.

In deciding Africa's position on the question of women's ordination, this article cannot endorse the ECD-BRC report, which concluded that this form of ordination is not biblical and should not be allowed. However, such a conclusion is based on their understanding of the (alleged) biblical prevalence for male ordination. It is the view of the author that the decision guiding the report is based on patriarchy and its cultural biases, which is outdated and untenable within the current church context and theological paradigm. As a way forward, the author suggests that the debate on women ordination in Africa should be given a proper critique by all stakeholders, including women.

\section{Acknowledgements Competing interests}

The author declares that she has no financial or personal relationships which may have inappropriately influenced her in writing this article.

\section{References}

Bauer, B.L., 2009, 'Christian worship and cultural diversity: A missiological perspective, Journal of the Adventist Mission Studies 5(2), 34-40.

Bekele, G., 2011, 'The biblical narrative of the missio Dei: Analysis of the interpretive framework of David Bosch's missional hermeneutic', International Bulletin of Missionary Research 35(3), 154-160, viewed 17 May 2015, from http:// eds.b.ebscohost.com.nwulib.nwu.ac.za/ehost/pdfviewer/pdfviewer?vid= $13 \&$ sid=91257df3-8d21-4aba-8534-73b7c860460a\%40sessionmgr113\&hid=112

Damstgeet, G.P., 1977, Foundations for the Seventh-day message and mission, William B. Eerdmans, Grand Rapids, MI, viewed 18 May 2015, from http://habakkukstables. $\mathrm{com} / \mathrm{wp}$-content/uploads/2013/09/Foundations-Of-The-SDA-Message-And Mission.pdf

Damstgeet, G.P., 1991, 'Seventh-day Adventist doctrine and progressive revelation', Journal of the Adventist Theological Society 2(1), 77-92, viewed 17 May 2015 from http://www.andrews.edu/ damsteeg/Prog\%20rev.html

Davis, J.J., 2014, 'On Paul's use of creation narratives', A periodical, viewed 17 May 2015, from http://eds.b.ebscohost.com.nwulib.nwu.ac.za/ehost/pdfviewer/ pdfviewer?vid=8\&sid=91257df3-8d21-4aba-8534-73b7c860460a\%40sessionmgr pdfviewer?vid
$113 \&$ hid $=112$

ECD-BRC, 2013, Seventh-day Adventist Churches of East-Central Africa Division of the General Conference ordination of women as pastors: Is it biblical? A Report to TOSC by East-Central Africa Division (ECD) Biblical Research Committee (BRC) viewed 20 May 2015, from https://www.adventistarchives.org/east-centralafrican-division-brc-report.pdf

Ewell, R.V.C., 2012, 'Missio Dei: The theological roots of evangelism', International Review of Mission 102(2), 385-387, viewed 17 May 2015, from http:// eds.b.ebscohost.com.nwulib.nwu.ac.za/ehost/pdfviewer/pdfviewer?vid= 14\&sid=91257df3-8d21-4aba-8534-73b7c860460a\%40sessionmgr113\&hid $=112$

Gaitskell, D. \& Urban-Mead, W., 2008, 'Transnational Bible women: Asian and African women in Christian mission', Women History Review 17(4), 489-500. http://dx. doi.org/10.1080/09612020802208750

Hiebert, P., 1976, 'Cultural differences in the communication of the Gospel', in A.F. Glasser et al. (eds.), Crucial dimensions in world Evangelization, William Carey Library, Pasadena, CA, viewed 18 May 2015, from http://www.worldevangelicals. org/resources/rfiles/res3_417_link_1341870903.pdf

Jardim, L.G., 2011, Recovering the female voice in Islamic Scripture: Women and silence, Ashgate, Burlington, VT.

Kemper, T., 2014, 'The missio Dei in contemporary context', International Bulletin of Missionary Research 38(4), 188-190, viewed 17 May 2015, form http:// eds.b.ebscohost.com.nwulib.nwu.ac.za/ehost/pdfviewer/pdfviewer?vid= $12 \&$ sid=91257df3-8d21-4aba-8534-73b7c860460a\%40sessionmgr $113 \&$ hid $=112$

Mckelwee, J.J., 2015, 'Vatican event tackles women equality, inclusion and ordination', viewed 17 May 2015, from http://eds.b.ebscohost.com.nwulib.nwu.ac.za/ehost/ pdfviewer/pdfviewer?vid=5\&sid=91257df3-8d21-4aba-8534-73b7c860460a $\% 40$ sessionmgr113\&hid=112

Nadar, S., 2012, 'Feminist theologies in Africa', viewed 19 May 2015, from http:// ir.nmu.org.ua/bitstream/handle/123456789/140884/4d60d1105d53c8f76603d3 ede5f94896. pdf? sequence $=1 \#$ page $=286$ 
Paulien, J., 2011, 'The unpredictable God: Creative mission and the biblical testimony' in L.B. Bauer (ed), A man of passionate reflection: A Festschrift honoring Jerald Whitehouse, Andrews University Mission Studies - VIII, Berrien Springs, MI.

Phiri, I., 2011, 'African women's theologies in the new millennium, Agenda: Empowering women for gender equity', International Review of Mission 18(61), 16-24. http://dx.doi.org/10.1080/10130950.2004.9676034

Piotrowski, G.N., 2011, 'The mission of God's people: A biblical theology of the church's mission', A Review 35(4), 378-379, viewed 20 May 2015, from http:// eds.b.ebscohost.com.nwulib.nwu.ac.za/ehost/pdfviewer/pdfviewer? vid=9\&sid=3548c57f-d25e-4a11-8b7d-afd4fa $4 \mathrm{f} 3 \mathrm{f} 3 \mathrm{f} \%$ 40sessionmgr $110 \&$ hid $=103$

Piper, J., 2010, Let the nations be glad: The supremacy of God in mission, Baker Academic, Grand Rapids, MI.

Russel, L.M., 2004, 'Cultural hermeunetics: A post colonial look at mission', Journal of Feminist Studies in Religion, 20(1), 23-40, viewed 02 September 2016, from http://www.jstor.org/stable/pdf/25002488.pdf

Tenety, E., 2015, 'Who am I to lead? Female leadership for the 21st century', $A$ Periodical, viewed 17 May 2015, from http://eds.b.ebscohost.com.nwulib.nwu. ac.za/ehost/pdfviewer/pdf $60460 \mathrm{a} \% 40$ sessionmgr113\&hid $=112$

General Conference Session (GCS), 2015, The 60 2015 General Conference Session of the Seventh - day Adventist world church, viewed 02 Septemeber 2016, from http://2015.gcsession.org/en/
Tim, R.A., 2014, Seventh-Day Adventists on women ordination: A brief historical overview, viewed 17 May 2016, from https://www.adventistarchives.org/ overview, viewed 17 May 2016, from https://www.adventistarchives.org/
seventh-day-adventists-on-womens-ordination-a-brief-historical-overview.pdf

Wari, G., 2009, Role and function of religion in Africa: An Adventist response, Journal of the Adventist Mission Studies 5(2), 34-40.

White, E.G., 1903, Education, Pacific Press, Mountain View, CA

White, E.G., 1880, 'The call of Moses', Signs of the Times, 26 February 1880, Acts of the Apostles, p. 94

Williams, D.M., 2010, 'Theology as a witness: Reading Scripture in a new era of Evangelical thought', A Periodical 36(2), 71-85, viewed 20 May 2015, from http://eds.b.ebscohost.com.nwulib.nwu.ac.za/ehost/pdfviewer/pdfviewer? vid $=4 \&$ sid $=3548 c 57 f-d 25 e-4 a 11-8 b 7 d-a f d 4 f a 4 f 3 f 3 f \% 40$ sessionmgr $110 \&$ hid $=103$

Williams, M., 2015, 'Serving God's people: Protestant women', viewed 17 May 2015 from http://eds.b.ebscohost.com.nwulib.nwu.ac.za/ehost/pdfviewer/pdfviewer?
vid=6\&sid=91257df3-8d21-4aba-8534-73b7c860460a\%40sessionmgr113\&h vid $=6 \&$
$\mathrm{id}=112$

Wright, C.J.H., 2006, The mission of God: Unlocking the Bible's grand narrative, IVP Academic, Downers Grove, IL.

Wright, C.J.H., 2010, The Mission of God's People: A Biblical Theology of the Church's Mission, Zondervan, Grand Rapids, MI. 